\title{
Leadership, Governance, and Poverty in Nigeria
}

\author{
Omoyibo, Kingsley Ufuoma (Ph.D.) \\ (Associate Professor) \\ Department of Sociology and Anthropology \\ Faculty of Social Sciences \\ University of Benin, P. M. B. 1154, Benin City, Edo State, Nigeria \\ Phone Number-+234-803-35424-67. Email: ufuomaomoyibo@hotmail.com
}

\section{Doi:10.5901/mjss.2013.v4n6p29}

\begin{abstract}
The National Bureau of Statistics has said that 112.519 million Nigerians live in relative poverty conditions. The absolute measure puts the country's poverty rate at 99.284 million. This paper attributes the poverty facing Nigerians to incompetent leadership and bad governance. Using Michael Lipton's theory of 'urban bias' which posits that there is more poverty in the rural areas because of the existence of parasitical and corrupt urban elites, this paper points out that people in rural areas are most affected by poverty due to marginalization by government. It points out how bad governance has led to the persistence of the Dutch disease (or mono-cultural economic policy) and its effect on poverty. It also highlights the effect of corruption the misuse of entrusted power for private gain - on poverty. The paper then presents a historical comparison of the effect of good leadership and bad leadership on poverty in Edo state since its creation in 1991. It concludes with cogent recommendations on the role of the government, the international community and the poor masses in tackling poverty via good leadership and governance.
\end{abstract}

Keywords: Corruption; Dutch Diseases; Governance; Leadership; Poverty.

\section{Introduction}

The National Bureau of Statistics has said that 112.519 million Nigerians live in relative poverty conditions. The absolute measure puts the country's poverty rate at 99.284 million or 60.9 percent. This is staggering when compared with the country's estimated 163 million population. According to the same report, the North-West and North-East recorded the highest poverty rates in the country in 2010 with 77.7 percent and 76.3 percent respectively. On the other hand, the South-West geo-political zone, recorded the lowest at 59.1 percent. Among the 36 states of the federation, the report stated that Sokoto had the highest poverty rate (86.4\%), while Niger had the lowest at 43.6\% (Onuba, 2012).

The above statistics shows that poverty walks on four legs in Nigeria. "It remains a paradox however, that despite the fact that the Nigerian economy is growing, the proportion of Nigerians living in poverty is increasing every year", laments Onuba (2012). According to Francis et al (quoted in Aghedo, 2013), "GDP per capita is 2,400 USD, and poverty is widespread - about $50 \%$ live on less than $\$ 1.25$ per day." But why so much poverty despite the abundant material resources of the country and recent economic growth? Yusuf (2010) answers: "Nigerians have seen a number of ineffective governments with various leaders betraying the trust of the people and people have no say over how they are governed and how accountable their government is to them." The above statement implies that there is a strong relationship between poverty and governance. Based on empirical evidence from many countries, a recent World Bank report concluded that "collectively, these studies provide overwhelming evidence that good governance is critical for successful development ... improves the wellbeing of the poor ... is important for poverty reduction" (Ojameruaye, 2012). With regards to the numerous programmes directed at poverty reduction overtime in the country, Ojameruaye (2012) asserts that "without a significant improvement in governance, much of the resources devoted to poverty reduction will be captured by politicians, contractors, and bureaucrats." The department for International Development concurs when it identified good governance as the panacea for tackling the high rate of poverty in the nation (Aboderin, 2013). 


\section{Statement of the Problem}

Despite the recent economic growth and the abundant human and material resources in Nigeria, a plethora of its citizens wallow in both absolute and relative poverty hinged on incompetent leadership and bad governance.

\section{Objective of the Study}

The study aims to point out a few areas where governance and leadership have failed, with specific reference to corrupt leadership and the Dutch disease. The study employs Michael Lipton's theory of 'urban bias' as a theoretical framework to reveal how bad governance has contributed to poverty being much more prevalent in rural Nigeria than in its urban centres. It also presents a historical-comparative analysis of successive leadership and governance in Edo state since its creation to point out the influence of both bad and good leadership/governance on poverty. Lastly, it makes recommendations on the way forward with regards to the role of effective leadership and good governance in tackling and curbing poverty in Nigeria. The study relies solely on secondary sources of data for its findings and analysis.

\section{Conceptual Orientation}

The concepts, leadership and governance are not new in literature and have been defined and/or described by many a scholar. For example, Terry (quoted in Dimowo and Shaibu, 2005:187) defines leadership as the "activity of influencing people to strive willingly for a group objective." Mullins (quoted in Yusuf, 2010) said that "leadership is a process in which the leader and followers interact such that the leader influences the actions of the followers towards the achievement of certain aims and objectives." Also, Anazodo et al, (2012:126) defines leadership as "a process of influencing, directing and co-coordinating the activities of organized groups towards goal setting, goal achievement, and problem solving, that it necessarily involves taking initiative or initiating new structures and new procedures and that is imperatively a function of the leader and the situational variable." The above definitions point out that leadership involves two parties - the leader(s) and followers. However, it is obvious that the leader is more involved in the leadership process than the followers. "Leadership is a non-coercive capacity, and followers willingly consent to be influenced or directed by the leadership" (Yusuf, 2010).

What about governance? Adamolekun (2006) simply views governance as the "process of exercising political power to manage the affairs of a nation." However, some scholars prefer to use the term "good governance" in describing governance. This is hinged on the fact that there can be 'bad governance' which is 'good governance' turned upside down. According to Lawal et al (2012), "good governance is a manifestation of committed, patriotic, and disciplined leadership." The World Bank (quoted in Lawal, 2012) defines good governance as "the means of exercising power in the management of a nation's economic and social resources for sustainable development." A more elaborate description of good governance is given by Healey and Robinson (quoted in Lawal,2012) as "a high level of organizational effectiveness in relation to policy formulation and the policies actually pursued, especially in the conduct of economic policy and its contribution to growth, stability, and public welfare." Yusuf (2010) also presents a nearly exhaustive description when he said that "good governance implies a situation where majority say is respected; where government strives in all its policies and actions to provide a better life for the majority; where social inequities are minimized; where all stakeholders respect the rule of law and where the conduct of government is transparent and accountability is institutionalized."

If we peer carefully into the above concise definitions and descriptions of leadership and governance, we will note that leadership involves more of influencing people than governance. Thus, there is a slight difference between leadership and governance. In fact, as one of the above definitions reveal, governance is a consequence of leadership. However, if we ponder on the basic meaning of the words 'lead' (from which leadership is derived), and govern (from which governance is derived) as used by most dictionaries - i.e. to control - we can say that 'leadership' is twinned with 'governance'. Consequently, for the sake of convenience, this paper shall use the concepts interchangeably when appropriate.

Put simply, poverty is "a state in which resources, usually material but sometimes cultural, are lacking" (Scott and Marshall, 2005:512). It is a "condition of having insufficient resources or income" (Microsoft Encarta Premium, 2009). However, scholars have defined poverty in two terms - subsistence (also called absolute/extreme poverty) and relative. Absolute poverty describes "a situation in which people barely exists, where the next meal may literally be a matter of life or death" (Webster, 1990:16). It describes "a lack of basic human needs such as adequate and nutritious food, clothing, 
housing, clean water and health services" (Microsoft Encarta Premium, 2009). On the other hand, "relative poverty accesses disadvantage in wider terms than the subsistence approach and so usually produces a much wider figure of those said to be in poverty" (Webster, 1990:18). It is the "comparison of the living standards of people living in a given society within a specified period of time" (Onuba, 2012). Townsend (quoted in Webster, 1990:20) describes relative poverty as "a process of encroaching deprivation by which people gradually slip out of the mainstream of social life, almost unnoticeably, without being the stereotype paupers in rags and tatters." On the basis of the above analysis, this paper shall use the concepts, 'poverty', 'absolute poverty', and 'relative poverty' distinctly wherever they may apply.

\title{
5. Theoretical framework
}

A national data provided by UNDP (2004) revealed that poverty is more prevalent in rural areas compared to urban areas. While over $70 \%$ of Nigerians are classified poor, the people in rural areas are most affected (Joe, 2012). On the basis of the facts above, Michael Lipton's theory of 'urban bias' (as presented in Webster, 1990:92-94) was used as a framework to point out how bad governance has contributed to poverty being widespread in the rural areas as compared to the urban areas.

Michael Lipton's theory of urban bias is an explanation for distorted, uneven development in the Third World. This theory places particular emphasis on the advantages that the urban centres in the world enjoy by cashing on most of the development aids and exploiting the surrounding rural regions. Lipton believes that the main reason why development is held back in the Third World and 'why poor people stay poor' is because of the existence of parasitical and corrupt urban elites. In defending his thesis, Lipton presents a mass of evidence that shows how little of the real investment capital that is available goes to the agricultural sectors, and what does tend to go to the more prosperous farmers: while poor farmers are very efficient, it is the richer ones that receive the cheap loans and subsidized fertilizer. Lipton's theory applies significantly to the Nigerian situation. People in rural areas are said to be most affected by poverty for many reasons including "marginalization from government" (Joe, 2012). "Governments insensitivity to the needs of the poor, poor policy implementation and inability to evenly develop the urban and rural areas, contribute to poor standards of living in the rural areas" Ibid. Ebirim (2011) also admits that "rural dwellers are underserved in terms of social and economic activities like welfare and other forms of reforms such as trade and industry; electricity and pipe-borne water. Absence of these makes them more prone to poverty."

Lipton's theory goes on to posit that when urban elites advocate for the development of the rural sector, it is not geared towards improving the lot of the rural poor, but to increase revenue for cash crops, most of which will go to support the urban centres. With regards to the above position, Ebirim (2011) reveals:

\begin{abstract}
"Rural poverty can be traced back to the British colonial administration from 1900-1960. Rural areas were neglected as a matter of deliberate policy. Community development both in theory and practice were not a priority of the colonial authorities. The extension of basic infrastructural facilities to the rural areas (if any) was only undertaken when it served their exploitative interests and long term goals. When Nigerian leaders took over, they preferred the sustenance of the status quo and the enhancement of the dichotomy and social inequalities to the disadvantage of the rural poor. The emergent Nigerian elites saw themselves as constituting a class ... and failed to embark on even progressive development of both areas."
\end{abstract}

The rural areas are probably seen by the government as only a home for farmers (Joe, 2012).

According to Lipton, the inability of Third World countries to develop the entire society through profit oriented industrial growth brings about a massive imbalance between the city and the country. That is why Ojameruaye (2012) is of the view that "the vast oil wealth of the country; the beautiful and opulent buildings in Lagos, Abuja and the various GRAs in our cities are not a measure of how well we have tackled poverty but how badly we have failed to address the issue." Rural development has long been neglected in Nigeria," because according to Joe (2102), "investments in health, education, roads, water supply and other social amenities have largely been concentrated in the cities. As a result, the rural population has limited access to safe drinking water, good roads, good health system, and quality education among others." In the same vein, Fagbenro-Byron attributes the increasing rate of poverty, especially in the rural areas to reasons including over concentration of basic amenities in the urban centres (Aboderin, 2013).

Lipton believes that the only way in which genuine mass development can occur is through a dramatic change in policy favouring a shift of resources to the rural poor. Hon. Rotimi Amaechi, the Governor of Rivers state submits to Lipton's recommendation when he said that "government must not be for one section of the society. It must be for the rich and the poor, emphasizing the upliftment of the poor." Correspondingly, Dr. Babangida Aliyu gave his fellow 
governors the following exhortation: "let us not as Governors concentrate on cities and go about bragging that we have worked. The people in the rural areas need more attention than those in the cities."

\section{The Dutch Disease and Poverty in Nigeria}

The Dutch disease (DD) is also termed "mono-cultural economic policy". It "is an economic policy whereby only one commodity forms the major exportable commodity resulting in severe economic instability and vulnerability to the price behavior of the commodity (Fadeyi and Adisa, 2012:132). It has also been defined as a "situation in which the discovery of a primary mineral resource anywhere in the world, instead of boosting exploitation and harmonious development of the economy, rather leads to decline or total collapse of economic activities in other sectors" (Bature, 2011:16). A study carried out by Bature (2011) confirms that the "Dutch disease has significant impact on the Nigerian economy". According to the FGN (quoted in Bature, 2011), "the discovery and exploitation of petroleum in commercial quantity in Nigeria, particularly during the oil boom periods of the 1970s and 1980s led to parallel declines of economic activities in other sectors, principally the agricultural sector of the economy and the major foreign exchange earner for the country as well as the major sector providing employment for over $80 \%$ of Nigeria's population." In addition, Adedeji (quoted in Bature, 2011) maintained that the "agricultural sector had, at independence in 1960 alone contributed about $65 \%$ of the total output and accounted for about $90 \%$ of foreign exchange earnings from exports and $80 \%$ of total employment."

In Nigeria, the DD scenario brought about changes in governments and other serious forms of instability, leading to coup d'états and rebellious groups that have often left hundreds of thousands of people dead and millions in misery and poverty (Bature, 2011). Besides, Gambo and Mai-lafia (quoted in Bature, 2011) points out that "more tragic was the gross incompetence of the leadership to use the financial resources generated through the sale of oil to mitigate the structural distortions in the economy" (italics ours). Consequently, it is more than obvious that the existence of oil has made Nigeria economically worse off than she could have been. Since the attention of government has turned to other sectors of the economy, production activities in the other sectors such as agriculture, mining, manufacturing and local industries, just to mention a few have been largely neglected to the detriment of those who have been active in those sectors (Bature, 2011). Utomi (2003) who described the DD as "the ultimate Achilles Heel of the Nigerian economy" laments that "the real trouble with our commonwealth in Nigeria, is however, that we cannot seem to find a way of preventing oil from continuing to deepen our misery and pronounce our destitution." He also decried how spending goes out of control each time oil prices go up and how rent champions head for the foreign exchange market to move money out which results in the persistence of the rage of poverty.

Without mincing words, we can say that bad governance and bad leadership has continued to accelerate the perpetuation of the existence of the DD in Nigeria, which has consequently continued to deepen the poverty of Nigerians. The inability of the government to manage the economy and cure the DD as it were has not only deepened poverty but has also resulted in corruption which is an aspect of failed leadership that the next section will peer into. It will also reveal how corruption has engendered or spawned poverty among Nigerians.

\section{Corrupt Leadership and Poverty in Nigeria}

If we embark on an exhaustive analysis of corrupt leadership and governance in Nigeria and how it has fostered and nurtured poverty among her citizenry, we believe we might keep writing till the end of our lives. However, this section will present a nutshell analysis of how corrupt leadership and governance has perpetrated and perpetuated poverty among Nigerians.

Transparency International defines corruption "as the misuse of entrusted power for private gain." Altas considers corruption as "a symptom of dysfunctionality of the relationship between the state and the people, characterized by bribery, extortion, and nepotism." Akcay notes that corruption "increases income inequality and poverty" (all quoted in Igwe, 2010:89). Corruption bears heavily on economic development and contributes to the affluence of a few which leads to a situation of a few affluent amidst a sea of people who live in acute squalor. It fosters unaccountable governance as the leadership crew strives to prevent the masses from getting to know exactly how much funds are acquired and how they are put to use. Corruption is both a cause of poverty, and a barrier to overcoming it. Noteworthy is the observation that one of the biggest challenges facing Africa (particularly Nigeria) is the need for better governance in terms of less corruption (Igwe, 2010). "In retrospect, corruption crept into the Nigerian system immediately after independence in 1960. And even if the magnitude was nothing compared to the level it has now assumed, it was still prevalent, particularly among government officials and politicians" (Idowu and Oyinlola, 2006:488; italics ours). With 
regards to the depth of corruption in Nigeria, Professor Adeyeye (quoted in Yusuf, 2009:425) said that "what we have in Nigeria is ... a corruptocracy; a government of the corrupt by the corrupt and for the corrupt. And in that kind of government, there are no rules because anything goes." He has "often maintained that government in Nigeria is a cesspool of corruption, an oasis of immorality ... which has occasioned the endemic poverty ravaging the land" (Yusuf, 2009:423-24). One of the devastating effects of corruption on the Nigerian society according to Idowu and Oyinlola (2006:492) is the "pauperization of the citizenry." In the same vein, Buba (200?) notes that "instead of focusing on delivering essential public services, some government officials choose to enrich themselves and their immediate family members through looting. Corruption, favouritism, and nepotism now strive in the country without regard for the needs of the common man."

The military era was the most unprecedented in corruption by leaders in Nigeria. In October 2006, the then president of the World Bank, Paul Wolfowitz disclosed that Nigerian officials had stolen more than $\$ 300$ billion of their nation's wealth over the last forty years (Igwe, 2010:102). One can only imagine how much this amount of money would have contributed in lifting millions of Nigerians out of their situation of deprivation! It is important to consider the terribly bad example of late Gen. Sani Abacha whose family was "accused of stealing $\$ 4$ billion property of the federal republic of Nigeria" (Olorunfewa, 2000:117). With regards to the Mephistophelian acts of Abacha himself who was described "as the Commander-in-Thief of the most venal and corrupt regime Nigeria has ever had" (quoted in Igbinovia, 2003:36), Idowu and Oyinlola (2006:489) puts it succinctly:

\begin{abstract}
"Sani Abacha stole the nation blind, paralyzed the machinery of governance and pauperized the citizenry in five years of dictatorship and frenetic looting. He dipped his hands in Central Bank of Nigeria's vaults 29 times between 1993 and 1998 , and stole $\$ 1.13$ billion and 413 million pounds. This did not include $\$ 386.2$ million as well as returns from fictitious and inflated contracts, which he ordered to be transferred into bank accounts abroad. As it were, he not only pocketed security votes but also engaged in direct printing of the nation's currency, among other heinous acts. By the time he died in 1998, Abacha had corruptly enriched himself and the family by as much as $\$ 3$ billion lodged in more than 130 bank accounts at home and abroad."
\end{abstract}

With regards to the corruption of Nigerian leaders as a whole during the military epoch, Randall Robinson notes: "It is well known that the Nigeria generals have siphoned off and deposited in dedicated accounts across the world, billions of dollars. So Nigeria that should be great has been brought to the verge of destruction by these rapacious, greedy and corrupt generals" (quoted in Igbinovia, 2003:32). Civilian leaders or administrators are not left out as they have often been accused of setting up several conduit pipes for looting their state treasuries, thus bringing misery to their people (Igbinovia, 2003). For example, the following former civilian governors were on trial two years ago for corruption related offences:

- Abdullahi Adamu of Nasarawa state for alleged misappropriation and embezzlement of about \#15 billion.

- Joshua Dariye of plateau state for corruption and money laundering involving \#1.2 billion, \$110,000 and 20,000 pounds.

- Chimaraoke Nnamani of Enugu state for illegal diversion and embezzlement of \#5.2 billion from allocations of local government councils.

- Saminu Turaki of Jigawa state for illegally diverting over \#33 billion and \$20 million public funds.

- Peter Odili of Rivers state for alleged misappropriation of \#89 billion, both in local and foreign currencies. (Source: Agbo, 2011:46)

Corrupt leadership is still running at full throttle in Nigeria. The consequence has been the uneasy co-existence of corrupt leaders who live in opulence and masses that live in indigence. In fact, Gallup Poll (2013) just revealed "that most Nigerians rate their country's leadership as the second most corrupt in the world." This view according to the poll was held by 94 percent of Nigerians who believed that there is widespread corruption in government. No doubt, corruption has pushed millions of Nigerians against the wall; and like the proverbial dog who when chased to the wall has no choice but to turn back and fight, something has to be done.

\title{
8. Leadership, Governance, and Poverty in Edo State: A Historical Comparison
}

No where in the Federal Republic of Nigeria have a people been so systematically alienated from enjoying their fundamental rights to good governance and development like in Edo state. For years, the masses of Edo state were neglected and despised. However, the leaders played fowl and dirty; and engaged themselves in a rat race of self preservation. This situation was to take a turn around with the emergence of Comrade Adams Oshiomhole as Governor 
of Edo state, which will prove how good leadership and governance can alleviate poverty. Before proceeding to discuss how the present leadership of Governor Adams Oshiomhole started taking steps to ameliorate poverty by his giant stripes in infrastructural, socio-economic and educational revamping and development of a hitherto comatose state, we shall briefly present the history of the state and the challenges she faced overtime.

Edo state has eighteen local government areas and a population of about 2.5 million persons. It has tree crops like rubber and oil palm. The state is equally very rich in solid minerals like limestones, gypsums, gold, marble, clay, et al. The people of Edo state are very hard-working and specialize in the following: wood works, bronze casting, cloth weaving, and ceramics. The state booms with forest products like splendid tropical tree species that are ready made raw materials for the furniture industry. Unfortunately, the state is popularly referred to as a civil service state because since its creation in 1991, no regime has been able to utilize her natural resources for developmental purposes. No thanks to bad governance! When the civilian administration of John Odigie (of the SDP) came into power in 1991, it did not last as the military later encroached and overthrew the democratically elected leaders in the country. The implication of military annexation was the appointment of different military administrators to oversee the affairs of the state. Consequently, rampaging and ruthless military administrators brought stark tragedy and hopeless rule to Edo state, thus, forcing the people in Edo state into a situation of deprivation. Supposedly, hope should have come to the poor masses with the enthronement of the democratic government of Chief Lucky Igbinedion. By their leadership however, the democratic government of Igbinedion (which lasted from 1999-2007) showed that they were not interested in the welfare of the people. Since the creation of Edo state, it is estimated that \#1trillion came to the state and more than half of that amount came during the administration of Lucky Igbinedion. Sadly, the collective verdict of honest, patriotic Edo state citizens was that Lucky Igbinedion's administration failed the people of the state woefully and dolefully. The events that occurred during his administration violated the spirit of governance; precipitated by incompetent leadership and insensitivity to the wishes and aspirations of the people. As nemesis would have it, on May 29, 2007, at the Samuel Ogbemudia stadium, Benin City, Chief Lucky Igbinedion was pelted with stones and sachets of water; he never escaped insults and affronts from the disenchanted and impoverished people of Edo state.

With the present administration of the state, we can say indisputably and indubitably that Comrade Adams Oshiomhole was ready to reverse the terrible and appalling situation of Edo state even before he took over power. Prior to his becoming the leader of the state, he noted: "To foster good governance which is a pre-condition for economic growth, wealth creation, public welfare, social justice and pro-poor policies requires the direct intervention of people of good conscience, clear vision, courage, and compassion ...." One can argue that to a large extent, Comrade Adams Oshiomhole has been able to tackle poverty headlong in the state. His main policy thrust has been the following:

- Collection and intensification of internal revenue generation (IRG).

- Creation of additional jobs.

- Construction and rehabilitation of roads across the state (not just Benin City).

- Drainage rehabilitation, flooding and erosion control.

- Provision of qualitative and affordable education and health care delivery services.

- Promotion of self-reliance and self- sufficiency in food and raw materials production.

- To combat poverty and enhance the quality of life of the people.

- Pursuit of peaceful and crime free society and improving the level of governance and development of a highly productive service.

No doubt, one can say that the present situation of Edo state is a consequence of good leadership and good governance simply by observing what has been done and what is being done. For example, unemployment is being tackled with the introduction of the Youth Employment Scheme (EDOYES), with different categories of youths being pulled out of the streets. The introduction of the Rapid Response Agency has also met with success. The Rapid Response Agency ahs the following mandate: emergency maintenance of roads and drainages; emergency provision of portable water and electricity; emergency reconstruction of public infrastructure; emergency provision of shelter, etc. Faced with the problem of cash flow to run his administration, Comrade Oshiomhole has repositioned and effectively placed the Internally Generated Revenue (IGR) of Edo state to a height unprecedented in the history of Edo state. This has greatly assisted his administration in fulfilling his developmental promises to the people of Edo state. Quite remarkably, some major achievements of his administration include: urban renewal projects; human capital development; youth and sport's development; educational development; road construction and rehabilitation amongst others. The above achievements are necessarily instrumental in tackling poverty. 
From the above historical-comparative analysis, our simple recommendation is that present and prospective leaders of Nigeria should borrow a leaf from the good leadership and good governance epitomized by Comrade Adams Oshiomhole and his team.

Source: Nowinta, I. (2012), Adams Oshiomhole: Conqueror of the godfathers, and the book: Adams Aliyu Oshiomhole: Thirty Six Months of Visionary Leadership, by the Press Unit, Government House, Benin City.

\section{Conclusion and Reccommendation}

It is glaring from the foregoing analysis that incompetent leadership and bad governance have led to poverty among the majority of Nigerians. The inadequacy of government to utilize petroleum resources wisely and the gross corruption that has been and is still being perpetrated by virtually all governmental officials and other stakeholders keeps rubbing salt into the wounds of poverty stricken Nigerians. Consequently, I make the following recommendations on the way forward:

- The leadership of the nation should give serious attention to human capital development and infrastructural development in rural areas in order to drastically curb the absolute poverty prevalent among rural Nigerians.

- The government should introduce programmes that can help poor Nigerians in their productive years to "entrepreneurially think and work their way out of poverty" (Utomi, 2003), instead of promising to give state jobs that cannot be available to every productive citizen.

- With regards to the DD phenomenon, I strongly agree with Bature (2011) who recommended that "harmonious development of the economy must be the priority of the government through the judicious use of revenue from the booming oil sector." The government should please, focus on reviving the agricultural sector and make it boom because it is a sector with potentials.

- Corrupt government officials must be punished before we can be on track to seeing the end to corruption. Impunity has served as immunity for corrupt governmental officials in Nigeria. Professor Adamolekun (2011) once said: "Unpunished corruption deepens corruption, when people are made to pay for their offences, it drastically reduces corruption." Those responsible for the sustained impoverishment of a rich nation like Nigeria should start paying through a quick conviction and appropriate long sentences (Agbo, 2011). The state should stop granting pardon to corrupt officials; it discourages deterrence and encourages deviance.

- Foreign governments should play their roles transparently by exposing the identity of individuals who keep bank accounts so that they can be prosecuted. They should also introduce policies that can help to retrieve stolen cash so that they can be used for developmental purposes back home (Bature, 2011).

- I also recommend that the government through the Independent National Electoral Commission (INEC) should keep improving the conduct of elections in Nigeria as they have been doing. And voters should not allow ethnic sentiments becloud their sense of reasoning in choosing their leaders. Rather, they should watch out for visionary and scrupulous leaders who yearn to help the poor masses, instead of voting for candidates who give them half bags of rice or bags of salt prior to elections or meager sums of money in the polling stations which can do, not little, but nothing to alleviate their impecunious predicament. Nigerian voters should avoid voting in political thugs or candidates introduced by corrupt political godfathers who are only interested in their self-aggrandizement and that of their godfathers.

\section{References}

Aboderin, M. (2013), "Good Governance, Panacea for Poverty." Retrieved from www.punchng.com on February 21, 2013.

Adamolekun, L. (2006), Politics, Bureaucracy, and Development in Africa. Spectrum Books Ltd: Ibadan.

Adamolekun, L. (2011), "Why Nigeria can't Fight Corruption." Ojiego, N. (ed) Vanguard, August 30. Page 6.

Agbo, A. (2011), "Trial of Ex-Governors: Another Offensive to Nowhere?" Tell. October 24.

Aghedo, M. I. (2013), "Elusive Peace: Understanding the Resurgence of Kidnapping in Post-Amnesty Niger-Delta, Nigeria." An Unpublished Monograph. Department of Political Science and Public Administration, University of Benin: Benin City.

Aliyu, M. B. (2013), "Deepening Democracy and Enhancing Public Welfare". Birthday Lecture for Comrade Adams Oshiomhole. Benin City, Edo State.

Anazodo, R., Okoye,J.C. and Ezenwile, U. (2012), "Leadership-Corruption: The Bane of Nigeria's Development." African Journal of Social Sciences, 2(3): 124-134. Retrieved from sachajournals.com/documents.pdf on March 4, 2013.

Bature, B. N. (2011), "An Evaluation of the Impact of the Dutch Disease on the Nigerian Economy (1970-2006)." A Ph.D Thesis submitted to the Department of Economics, University of Jos: Jos, Nigeria. Retrieved from dspace.unijos.edu.ng.pdf on March 4, 2013.

Buba, A. M. (20??), "Millennium Development Goals: The Nigerian Situation." Retrieved from www.gamji.com on February $12,2013$. 
Dimowo, F. A. and Shaibu, I. (2005), "Leadership" in Agbonifoh, B. A., Agbadudu, A. B. and lyayi, F. I. O. (eds) Management: A Nigerian Perspective. Malthouse Press Ltd: Lagos.

Ebirim, U. (2011), "A Typical Appraisal of Rural Poverty in Nigeria." Retrieved from www. academicexcellencesociety.com on February 21, 2013.

Fadeyi, A. O. and Adisa, W. B. (2012), Cultural Impediments to Socio-Economic Development in Nigeria: Lessons from the Chinese Economy." Journal of Sustainable Development, 5(7)127-136. Retrieved from www.ccsenet.org/journal/index.php.pdf on February 12, 2013.

Gallup Poll (2012), Nigeria's Leadership is Second Most Corrupt in the World." Retrieved from www.thisday.com on February 21, 2013. Idowu, L. and Oyinlola, A. (eds) (2006), "Standing up Against Corruption" in Tell: Courage in Print. Diamond Publications: Lagos.

Igbinovia, P. E. (2003), The Criminal in All of Us: Whose Ox Have We Not Taken? A Professorial Inaugural Lecture. Benin City: University of Benin.

Igwe, S. C. (2010), How Africa Underdeveloped Africa. Professional Publishers: Port-Harcourt.

Joe, P. (2012), "Curbing Rural Poverty in Nigeria." Retrieved from www.thetidenewsonline.com on February 21, 2013.

Lawal, T., Imokhuede, K. and Johnson, I. (2012), "Governance Crisis and the Crisis of Leadership in Nigeria." International Journal of Academic Research in Business and Social Sciences, (2)7: 185-191. Retrieved from www.hrmars.com/journals/pdf on February $21,2013$.

Microsoft Encarta Premium. (2009).

Nowinta, I. (2012), Adams Oshiomhole: Conqueror of the Godfathers. Image Communications/Lucky Diamond: Benin City.

Ojameruaye, E. (2002), "Governance and Poverty Reduction in Nigeria." Retrieved from www.nigeriaworld.com on February 21, 2013. Olorunfewa, A. (2000), "The Wages of Sleaze" in Idowu, L. and Oyinlola, A. (eds) Tell: Courage in Print. Diamond Publications: Lagos.

Onuba, I. (2012), "112.5 Million Nigerians live in Poverty - National Bureau of Statistics." Retrieved from www.libertyreport.com on February 21, 2013.

Press Unit, Government House, Benin City. (2012), Adams Aliyu Oshiomhole: Thirty Six Months of Visionary Leadership. BHG Press Ltd: Benin City.

Scott, J. and Marshall G. (eds) (2005), Oxford Dictionary of Sociology. Oxford University Press: New York.

Utomi, P. (2003), "Managing the Curse of Oil." Retrieved from www.waado.org/nigerdelta/essays/utomi-Oil.html on February 21, 2013.

Webster, A. (1990), An Introduction to the Sociology of Development. Macmillan Press: London.

Yusuf, H. A. (2010), "Leadership Role and Good Governance in Nigeria." Retrieved from www.imim-ng.org on February 21, 2013.

Yusuf, A. (2009), "We Run a Corruptocracy" in Idowu, L. and Oyinlola, A. (eds) Tell: Courage in Print. Diamond Publications: Lagos. 